\title{
Insight into the proteome of the hyperthermophilic Crenarchaeon Ignicoccus hospitalis: the major cytosolic and membrane proteins
}

\author{
Tillmann Burghardt $\cdot$ Manfred Saller $\cdot$ Sonja Gürster $\cdot$ Daniel Müller $\cdot$ Carolin Meyer $\cdot$ \\ Ulrike Jahn · Eduard Hochmuth · Rainer Deutzmann · Frank Siedler · Patrick Babinger • \\ Reinhard Wirth · Harald Huber · Reinhard Rachel
}

Received: 20 January 2008 / Revised: 21 May 2008 / Accepted: 9 June 2008 / Published online: 27 June 2008

(C) Springer-Verlag 2008

\begin{abstract}
Ignicoccus hospitalis, a hyperthermophilic, chemolithoautotrophic Crenarchaeon, is the host of Nanoarchaeum equitans. Together, they form an intimate association, the first among Archaea. Membranes are of fundamental importance for the interaction of I. hospitalis and $N$. equitans, as they harbour the proteins necessary for the transport of macromolecules like lipids, amino acids, and cofactors between these organisms. Here, we investigated the protein inventory of I. hospitalis cells, and were able to identify 20 proteins in total. Experimental evidence and predictions let us conclude that 11 are soluble cytosolic proteins, eight membrane or
\end{abstract}

Communicated by Erko Stackebrandt.

T. Burghardt · M. Saller · S. Gürster · C. Meyer $\cdot$ R. Rachel $(\bowtie)$ Centre for Electron Microscopy,

Faculty for Biology and Preclinical Medicine,

University of Regensburg, Universitätsstraße 31,

93053 Regensburg, Germany

e-mail: reinhard.rachel@biologie.uni-r.de;

reinhard.rachel@biologie.uni-regensburg.de

D. Müller · U. Jahn · R. Wirth · H. Huber

Institute for Microbiology, University of Regensburg,

Universitätsstraße 31, 93053 Regensburg, Germany

E. Hochmuth $\cdot$ R. Deutzmann

Institute for Biochemistry, University of Regensburg,

Universitätsstraße 31, 93053 Regensburg, Germany

P. Babinger

Institute for Physical Biochemistry, University of Regensburg,

Universitätsstraße 31, 93053 Regensburg, Germany

F. Siedler

Membrane Biochemistry, Max-Planck-Institute of Biochemistry,

Am Klopferspitz 18, 82152 Martinsried, Germany membrane-associated proteins, and a single one extracellular. The quantitatively dominating proteins in the cytoplasm (peroxiredoxin; thermosome) antagonize oxidative and temperature stress which I. hospitalis cells are exposed to at optimal growth conditions. Three abundant membrane protein complexes are found: the major protein of the outer membrane, which might protect the cell against the hostile environment, forms oligomeric complexes with pores of unknown selectivity; two other complexes of the cytoplasmic membrane, the hydrogenase and the ATP synthase, play a key role in energy production and conversion.
Present Address:

M. Saller

Department of Molecular Microbiology,

Groningen Biomolecular Sciences and Biotechnology Institute,

University of Groningen, Kerklaan 30, 9751 NN Haren,

The Netherlands

Present Address:

S. Gürster

Institute for Anatomy, University of Regensburg,

Universitätsstraße 31, 93053 Regensburg, Germany

Present Address:

D. Müller

Institute for Pathology, University Hospital,

University of Regensburg, Franz-Josef-Strauß-Allee,

93053 Regensburg, Germany 
Keywords Crenarchaeota - Chemolithoautotrophy · Proteome $\cdot$ MALDI $\cdot$ Ignicoccus hospitalis

\begin{tabular}{|c|c|}
\hline \multicolumn{2}{|l|}{ Abbreviations } \\
\hline MALDI-TOF MS/MS & $\begin{array}{l}\text { Matrix-assisted laser desorption/ } \\
\text { ionization-time of flight-tan- } \\
\text { dem mass spectrometry }\end{array}$ \\
\hline TEM & Transmission electron microscopy \\
\hline MES & Morpholino-ethane sulfonic acid \\
\hline DTT & Dithiothreitol \\
\hline SDS-PAGE & $\begin{array}{l}\text { Sodium dodecyl sulfate polyacryl- } \\
\text { amide gel electrophoresis }\end{array}$ \\
\hline PMSF & Phenylmethylsulphonyl fluoride \\
\hline PVDF & Polyvinylidenfluoride \\
\hline DDM & $\begin{array}{l}\text { Dodecylmaltoside, } \mathrm{n} \text {-dodecyl- } \\
\beta \text {-D-maltopyranoside }\end{array}$ \\
\hline
\end{tabular}

\section{Introduction}

Three species of the crenarchaeal genus Ignicoccus are described so far, I. islandicus, I. pacificus (Huber et al. 2000), and I. hospitalis (Paper et al. 2007). They are of special interest because of their unique features: their cell architecture is unusual among the Archaea (Rachel et al. 2002; Näther and Rachel 2004), and they live by strict chemolithoautotrophy, using molecular hydrogen as electron donor and elemental sulfur as electron acceptor, forming $\mathrm{H}_{2} \mathrm{~S}$ (Huber et al. 2000). Results of recent investigations make I. hospitalis particularly interesting and challenging: it uses a new and so far unique mode of $\mathrm{CO}_{2}$ fixation (Jahn et al. 2007; Huber et al. 2008), it has the second smallest archaeal genome known so far (http:// img.jgi.doe.gov), and it can serve as host of the only known archaeal 'symbiont/parasite,' Nanoarchaeum equitans (Huber et al. 2002; Jahn et al. 2008), which itself has the smallest archaeal genome known today (Waters et al. 2003).

The cell envelope of Ignicoccus cells has a number of unique features: it lacks any solid, rigid cell wall components, like pseudomurein or an S-layer, as found in most Archaea described today (König et al. 2007). Instead, the cells are surrounded by two membranes in a unique arrangement. The cytoplasmic membrane appears highly 'undulating' in electron micrographs of ultrathin sections; effectively, vesicles frequently bleb off into the periplasm or are taken up into the cytoplasm (Rachel et al. 2002; Paper et al. 2007; Junglas et al. 2008). The periplasm has a variable width of 20 up to $400 \mathrm{~nm}$ and contains membranebound vesicles, round or elongated in shape. It is surrounded by an outer membrane, which consists of archaeal isoprenyl diether lipids (Jahn et al. 2004) and of multiple $\left(\sim 10^{5}\right.$ to $\left.10^{6}\right)$ copies of a thermostable, pore-forming com- plex. This complex is an oligomer of a small membrane protein with a mass of $6.23 \mathrm{kDa}$ (Burghardt et al. 2007). The protein and lipid components of the cell envelope predetermine both the architecture and the basic lifestyle of I. hospitalis: for survival and growth, these cells depend on the effective uptake of small inorganic ions, sulfur, molecular hydrogen, and $\mathrm{CO}_{2}$. In addition, the cell surface and transporters as part of the cell envelope are assumed to be the determinants and key molecules for the specific interaction of I. hospitalis with $N$. equitans. For this reason, the detailed knowledge of the protein inventory of the cell envelope is mandatory for understanding the cell architecture of I. hospitalis alone as well as the cell-cell interaction between these two Archaea. Stimulated by the proteomic analyses of two Archaea, Halobacterium salinarum (Klein et al. 2005, 2007; Soppa et al. 2008) and Thermoplasma acidophilum (Sun et al. 2007), we have started to isolate and characterize the major proteins of I. hospitalis cells and, in particular, the cell envelopes by a combination of protein separation techniques using chromatography and/or sodium dodecyl sulfate polyacrylamide gel electrophoresis (SDS-PAGE), followed by protein identification using $\mathrm{N}$-terminal sequencing and/or matrix-assisted laser desorption/ionization — time of flight—-tandem mass spectrometry (MALDI-TOF MS/MS).

\section{Materials and methods}

Archaeal strains and growth conditions

The type strain I. hospitalis was obtained from the Culture Collection of the Institute for Microbiology, University of Regensburg. Cells were routinely grown in $1 / 2$ SME medium at $90^{\circ} \mathrm{C}$, as described previously (Huber et al. 2000; Paper et al. 2007), with elemental sulfur as electron donor and a gas phase consisting of $\mathrm{H}_{2} / \mathrm{CO}_{2}(250 \mathrm{kPa} ; 80$ / $20, \mathrm{v} / \mathrm{v})$. Batch cultures were grown in enamel protected fermentors $\left(50\right.$ or $300 \mathrm{l}$ ) at $90^{\circ} \mathrm{C}$ at constant stirring (150 rpm) and gassing of $\mathrm{H}_{2} / \mathrm{CO}_{2}(80 / 20, \mathrm{v} / \mathrm{v}$, at 2 or $\left.101 \mathrm{~min}^{-1}\right)$.

Cell homogenization and fractionation of cytosolic and membrane proteins

Frozen cells were suspended in a hypotonic buffer containing $5 \mathrm{mM} \mathrm{KH}_{2} \mathrm{PO}_{4}, 1 \mathrm{mM}$ EDTA-Na $2,1.4 \mathrm{mM} \mathrm{MgSO}$, $1 \mathrm{mM}$ PMSF, $\mathrm{pH}$ 4.4. Experiments using MES buffer (25 mM MES/NaOH pH 5.5, $237 \mathrm{mM} \mathrm{NaCl}, 2.5 \mathrm{mM}$ $\mathrm{CaCl}_{2}, 1.5 \mathrm{mM} \mathrm{MgSO}_{4}$, and $1 \mathrm{mM}$ PMSF) yielded essentially the same results. Homogenization using a glass Potter homogenizer (Näther and Rachel 2004; Burghardt et al. 2007) was used to lyse Ignicoccus cells. The cell lysate was 
directly applied onto a sucrose gradient $(8.5-70 \%, \mathrm{w} / \mathrm{v}$, in MES buffer), and separated by ultracentrifugation (2-3 h, $48,000 \mathrm{rpm}$, equivalent to $250,000 \times g$, Optima LE- $80 \mathrm{~K}$, SW60 rotor, Beckman Coulter). The resulting gradient was sampled into eight fractions, which were directly analyzed by SDS-PAGE. Proteins were identified by N-terminal sequencing or tryptic digestion and MALDI-TOF MS/MS. Proteins of the 'membrane fraction' were found in fractions ' $\mathrm{M}$ ' of the sucrose gradient (Fig. 1; cf. Burghardt et al. 2007); they were gently solubilized at $25^{\circ} \mathrm{C}$ for $60 \mathrm{~min}$ by adding $0.5 \%$ dodecylmaltoside (DDM; n-dodecyl-b-Dmaltopyranoside, Anagrade; Anatrace Inc., Maumee, $\mathrm{OH}$, USA), and the solution was subjected to ultracentrifugation (60 min, 48,000 rpm; equivalent to $100,000 \times g$; Optima MAX-E; TLA-55 rotor; Beckman Coulter). The pellet, which was resuspended in the same buffer and volume, and the supernatant were both tested for their protein content by SDS-PAGE. The proteins in the supernatant were separated by gel filtration (Hi Load 16/60 Superdex 200; Äkta; GE Healthcare, Munich, Germany), and then further analyzed, in order to identify proteins which are present in smaller amounts.

Using a different approach for identification of proteins present in both I. hospitalis membranes, the cytoplasmic and the outer membrane, the cell lysate was cleared from cell debris by a short centrifugation step (10 min,
$10,000 \times g)$. The membranes were concentrated by ultracentrifugation $(2 \mathrm{~h}, 48,000 \mathrm{rpm}$, equivalent to $250,000 \times \mathrm{g}$, Optima LE-80K, SW60 rotor, Beckman Coulter), followed by two rounds of resuspension in the same MES buffer, vortexing and ultracentrifugation. For analysis by SDSPAGE, the final sample was dissolved in a minimum volume of MES buffer and the protein concentration determined, before the sample buffer was added.

Denaturation of protein samples for SDS-PAGE was achieved in $2.5 \%$ SDS, $2.5 \mathrm{mM}$ DTT, $25 \mathrm{mM}$ Tris $/ \mathrm{HCl}$ pH 7.5, 5\% glycerol, and 5 mM EDTA- $\mathrm{Na}_{2}$ (all final concentrations) at $95^{\circ} \mathrm{C}$ for $15 \mathrm{~min}$. Protein separation on $10 \%$ acrylamide gels was essentially performed as described (Schägger and von Jagow 1987; Burghardt et al. 2007). Proteins were routinely detected using silver staining (Blum et al. 1987); in case of further analysis like $\mathrm{N}$ terminal sequencing or MALDI-TOF MS/MS, a Coomassie $\mathrm{R}$ staining was performed (Schägger and von Jagow 1987).

In comparative experiments, I. hospitalis cell lysates were also separated by isopycnic $\mathrm{CsCl}$ gradient centrifugation ( $48 \mathrm{~h}, 48,000 \mathrm{rpm}$, equivalent to $250,000 \times \mathrm{g}$, Optima LE-80K, SW60 rotor, Beckman Coulter), and the samples analyzed by SDS-PAGE, as above, and by transmission electron microscopy (TEM), as described (Burghardt et al. 2007).

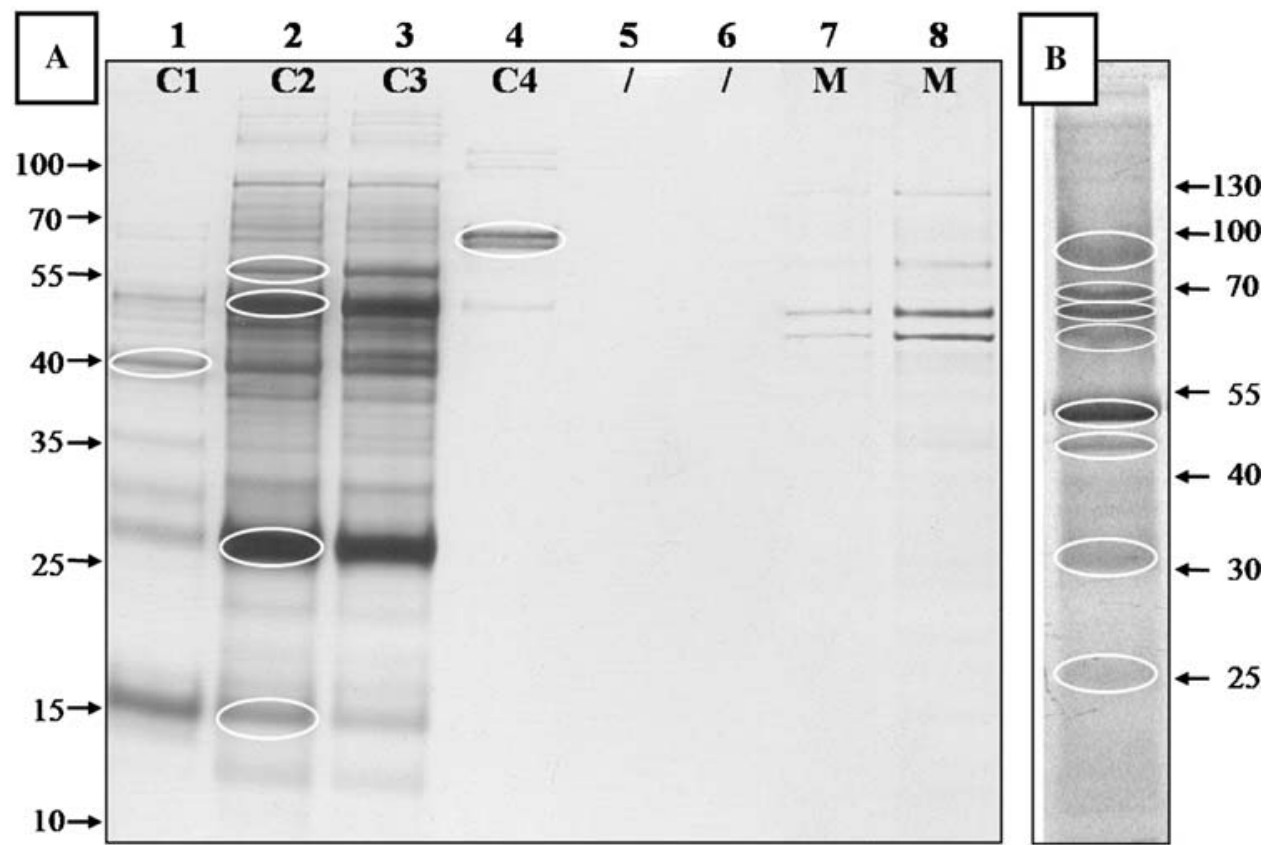

Fig. 1 Sodium dodecyl sulfate polyacrylamide gel electrophoresis of various protein samples of Ignicoccus hospitalis, stained with Coomassie. Numbers on the left (a) and on the right (b) indicate relative masses in $\mathrm{kDa}$. a Cell lysate was separated by sucrose gradient centrifugation, sampled into eight fractions and analyzed by SDS-PAGE. $1-$ 4, cytosolic (C1-C4), 5, 6 (no protein), and 7, 8, membrane 'M' (cf.
Fig. 1 from Burghardt et al. 2007). White ellipsoids indicate bands further analyzed by $\mathrm{N}$-terminal sequencing and/or mass spectrometry. $\mathbf{b}$ Total membrane protein sample of $I$. hospitalis obtained by ultracentrifugation and separated by SDS-PAGE. White ellipsoids mark bands which were further analyzed by N-terminal sequencing and/or mass spectrometry 


\section{Protein identification}

For N-terminal sequencing by Edman degradation (ABI Procise 492 Protein Sequencer; Applied Biosystems), proteins were transferred onto a PVDF membrane using standard methods (Transblot ${ }^{\circledR}$ Semidry, Bio-Rad, Munich, Germany). In case of proteins which turned out to be N-terminally blocked, proteins were separated by SDS-PAGE, Coomassie-stained, excised and completely destained, followed by in-gel digestion using Trypsin (sequencing grade; Roche Diagnostics GmbH, Mannheim, Germany). The digests were analyzed by peptide mass fingerprints and MS/ MS spectra of selected peptides (combined MS + MS/MS search) using a 4700 Proteomics Analyzer (ABI). Proteins were identified searching the non-redundant National Center for Biotechnology Information (NCBI) database release February 2008 using the Mascot search program (Matrix Science Ltd., London, England). Protein scores $>80$ (cutoff value) were statistically significant $[P<0.05$; score: $-10 * \log (P) ; P$ is the probability that the observed match is a random event]. A short note of caution: with the approach as described, we attempted to identify the dominant protein in a given band. If a protein band contains more than one protein, and the dominant protein is blocked and not digested by trypsin, this may result in the analysis of a minor protein in one band, which is more easily analysed by $\mathrm{N}$-terminal sequencing or trypsin digestion.

\section{Bioinformatic analysis}

The annotated genome sequence of I. hospitalis is deposited at the DOE Joint Genome Institute JGI (http://img. jgi.doe.gov/cgi-bin/pub/main.cgi) and also at the NCBI (http://www.ncbi.nlm.nih.gov/genomes/static/a.html; Refseq: NC_009776). Selected genes were compared with public databases: the PFAM database at the Sanger Institute (http://pfam.sanger.ac.uk/), the protein database at NCBI (http://www.ncbi.nlm.nih.gov/) using blastp, and with the Uniprot database at the EMBL-EBI (http://www.ebi.ac.uk/ uniprot/) using WU-Blast2 (http://www.ebi.ac.uk/blast2/). Molecular masses and isoelectric points $(\mathrm{pI})$ were calculated using ProtParam (Gasteiger et al. 2005; http://www.expasy.ch/tools/protparam.html). For signal peptide prediction, four programs were used. On http://signalfind.org, FlaFind, which predicts archaeal class III (type IV, pilin-like) signal peptides and their prepilin peptidase cleavage sites (Szabó et al. 2007), and TatFind, which predicts archaeal and bacterial twin arginine translocation (TAT) signal peptides (Rose et al. 2002); Phobius (http://phobius.sbc.su.se/) is designed as a combined transmembrane topology and signal peptide predictor (Kaell et al. 2007); and SignalP 3.0 (http:// www.cbs.dtu.dk/services/SignalP/), which was used with precaution only, because it is specifically designed for pre- diction of signal peptide cleavage sites in Eukaryotes, Grampositive and Gram-negative Bacteria, but explicitly excluding Archaea. Due to this dilemma, we have chosen 'Gramnegative Bacteria' as default. For prediction of transmembrane domains (TMDs) and as tools for classification and secondary structure prediction of membrane proteins, several programs were used: TMHMM 2.0 (http://www.cbs.dtu.dk/ services/TMHMM/; Krogh et al. 2001); SOSUI (http:// bp.nuap.nagoya-u.ac.jp/sosui/; Department of Applied Physics, Nagoya University, Japan); Phobius (see above), and HMMTOP (http://www.enzim.hu/hmmtop/; Tusnády and Simon 2001). Prediction of the possible 3D structure of proteins was done with 'Phyre' (http://www.sbg.bio.ic.ac.uk/ phyre/; Imperial College, London, UK).

\section{Results and discussion}

The concept of the experiments was derived from our previous study, in which we identified and characterized the major outer membrane protein of I. hospitalis cells (Burghardt et al. 2007). Basically, separation of cell lysate on a sucrose gradient resulted in fractions in the top half of the gradient, containing cytosolic proteins (Fig. 1a, fractions $\mathrm{C} 1$ to $\mathrm{C} 4)$. Two fractions in the lower third of the gradient (Fig. 1a, lane 7 and 8: M) contained membrane proteins; they were dominated by two bands at 45 and $50 \mathrm{kDa}$, in fact oligomeric forms of the major outer membrane protein 'Imp1227' (Burghardt et al. 2007). For a detailed analysis of these two fractions, they were solubilized by adding $0.5 \%$ DDM. The efficiency of this step was tested by SDSPAGE: more than $95 \%$ of all proteins were found in the supernatant, which were then separated by gel filtration (Fig. 2). Another approach to analyze the I. hospitalis membrane proteins started from membrane patches obtained from homogenized cells, followed by ultracentrifugation, SDS-PAGE and MALDI-TOF MS/MS (Fig. 1b). Biophysical and biochemical data of the identified proteins, including their putative subcellular localization are presented in Table 1. The protein sequences were compared with public databases like NCBI, EMBL-EBI, and PFAM; some of these data are compiled in Tables 2 and 3. Protein complexes and membranes in selected fractions of all preparations were also analyzed by TEM of negatively stained samples (cf. Burghardt et al. 2007).

The main cytosolic proteins

Ignicoccus hospitalis cells were lysed by freeze-thawing and Potter homogenization. Because the cells do not have any rigid cell envelope component like S-layer or pseudomurein, this treatment is sufficient for complete cell lysis. The homogenate was then subjected to sucrose gradient 


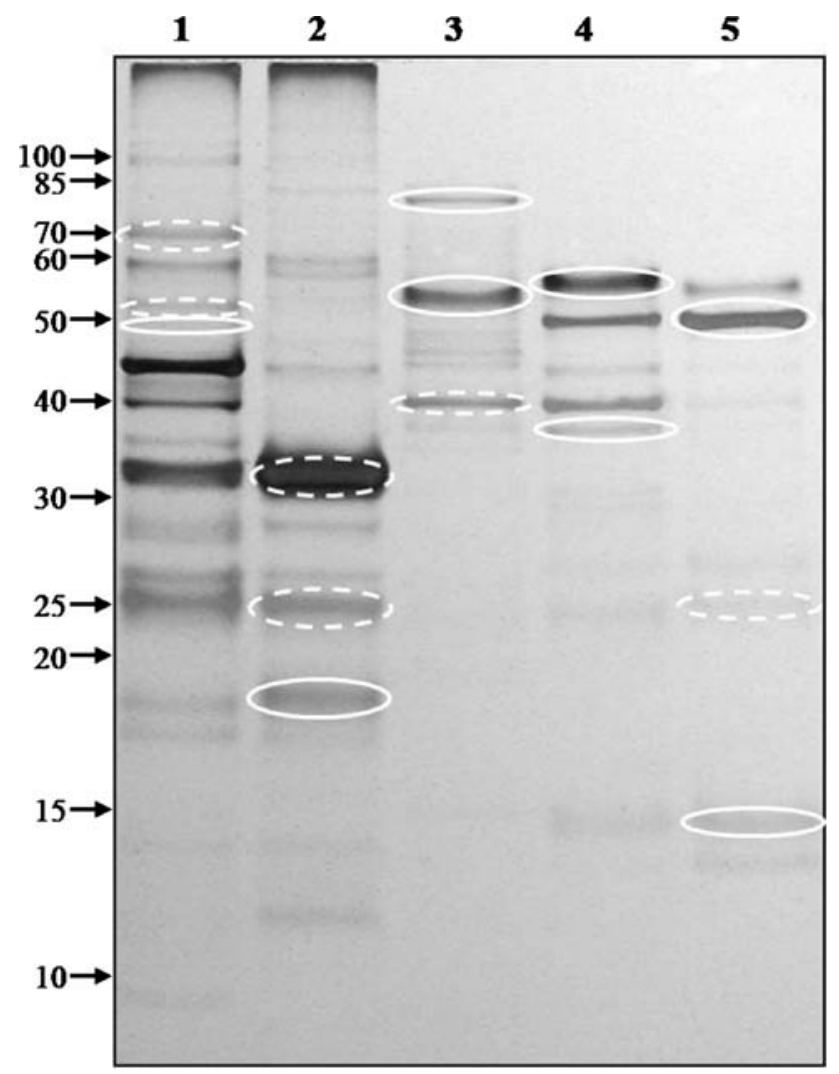

Fig. 2 Membrane samples of I. hospitalis, solubilized with $0.5 \%$ DDM, separated by gel filtration, analyzed by SDS-PAGE and stained with Coomassie. Numbers on the left indicate relative molecular masses (kDa). Numbers on top are arbitrary fraction numbers of the gel filtration chromatography. The white ellipsoids indicate samples further analyzed by N-terminal sequencing and/or mass spectrometry. Solid white lines indicate proteins which were newly identified; broken lines indicate proteins which had already been identified

centrifugation, and the resulting fractions analyzed by SDSPAGE (Fig. 1a; see also Fig. 1 in Burghardt et al. 2007). The cytosolic proteins in the upper half of the gradient (Fig. 1a: fractions $\mathrm{C} 1$ to $\mathrm{C} 4$ ), visible as distinct protein bands and marked by ellipsoids, were further analyzed.

In fraction C1 (Fig. 1a), a 40-kDa protein was identified based on its N-terminal seven amino acids ( $\mathrm{N}^{\prime}$-AKVVILG) and using MS/MS of tryptic peptides; it is encoded by gene igni_0899. The protein with 367 amino acids has a predicted mass of 41,020 Da. In the I. hospitalis genome, the product of gene igni_0899 is annotated as a member of the 'FAD-dependent pyridine nucleotide-disulphide oxidoreductases'. This protein family includes both class I and class II oxidoreductases and also NADH oxidases and peroxidases. From its proposed function and its abundance, this protein may act as a physiological reductant of the peroxiredoxin (Prx) Igni_0459; see below. When doing Blast searches against the non-redundant protein sequence database at NCBI, the first hit with the remarkable similarity of $67 \%$ identical amino acids was to a protein, which is annotated in the genome of $N$. equitans (locus_tag Neq024) as a hypothetical flavoprotein. Other similar proteins were annotated in genomes from several crenarchaeal species (Table 3), with the same putative function, referred to as flavoprotein reductase, or as oxidoreductase (flavoprotein).

Fractions C2 and C3 (Fig. 1a) always exhibited similar bands in SDS-PAGE analysis. Fraction C2, which was pink colored for unknown reasons, was analyzed further.

The N-terminus of the protein band with an apparent mass of about $56 \mathrm{kDa}$ was determined by Edman degradation to be $\mathrm{N}^{\prime}-[\mathrm{GA}] \mathrm{L}[\mathrm{Q} E] \mathrm{IMLI}$. The only gene in the $I$. hospitalis genome which might encode this protein is igni_0985, an uncharacterized protein of 138 amino acids and a predicted mass of $15,428 \mathrm{Da}$, whose proposed N-terminus is $\mathrm{N}^{\prime}$-MALEIMLI. Whether the $56 \mathrm{kDa}$ band in the SDS-PAGE contains an oligomer of this protein which was not dissociated under the conditions employed, remains unclear. No function can be proposed yet: no protein with significant similarity was found in the databases tested. The bioinformatic analysis confirms that this is an enigmatic protein: SignalP predicts a leader peptide, a result which is in contradiction to the result of the direct $\mathrm{N}$-terminal sequencing; the protein is found in a fraction of the sucrose gradient with cytoplasmic proteins, but Phobius and TMHMM predict that it contains three transmembrane helices. Detailed biochemical analyses are needed to solve these questions.

The by far dominating protein bands were found at relative masses of 50 and $25 \mathrm{kDa}$, as determined by SDSPAGE. For these two bands, and in addition for a band with an apparent mass of $15 \mathrm{kDa}$, a single protein $\mathrm{N}$-terminus was found ( $\mathrm{N}^{\prime}$-PGQIPLI), encoded by gene igni_0459 (annotated N-terminus: MPGQIPLI). The protein is predicted to have 234 amino acids and a mass of 26,711 Da. The comparison of its sequence with public databases (PFAM; EMBL-EBI; NCBI) helped to identify this protein as a member of the Prx family, also named alkyl hydroperoxide reductase (AhpC), thiol specific antioxidant (TSA; EC 1.11.1.7), or thioredoxin peroxidase-enzymes, which are described as a peroxide-scavenging system. Prxs are known to form stable dimers, which can explain the $50 \mathrm{kDa}$ band observed in our experiments (Nakamura et al. 2006). The band at $15 \mathrm{kDa}$ might be a proteolytic product of the native Prx. Prxs are a family of TSA proteins, which are able to reduce reactive oxygen and nitrogen species and also organic hydroperoxides $(\mathrm{ROOH}+2[\mathrm{H}] \rightarrow \mathrm{ROH}+$ $\mathrm{H}_{2} \mathrm{O}$; Wood et al. 2003; Limauro et al. 2006; Boucher et al. 2006). Reduction of the Prxs involves the action of a flavoprotein disulfide reductase (e.g., Igni_0899) and at least one additional protein containing a CXXC motif, thioredoxin reductase and thioredoxin (Wood et al. 2003); these two proteins were not found in our study, but one gene coding for a protein with a thioredoxin domain is annotated in the 


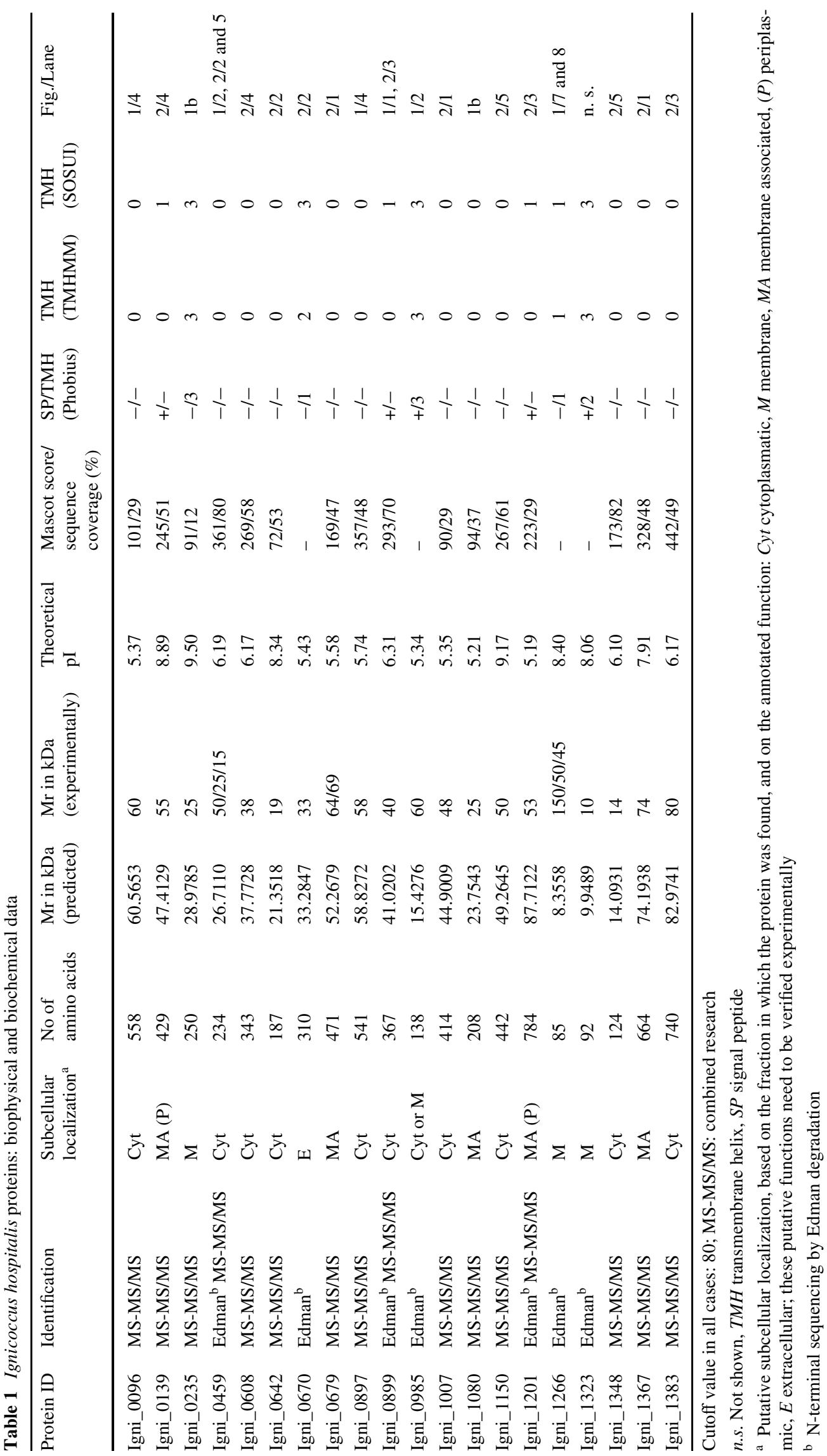




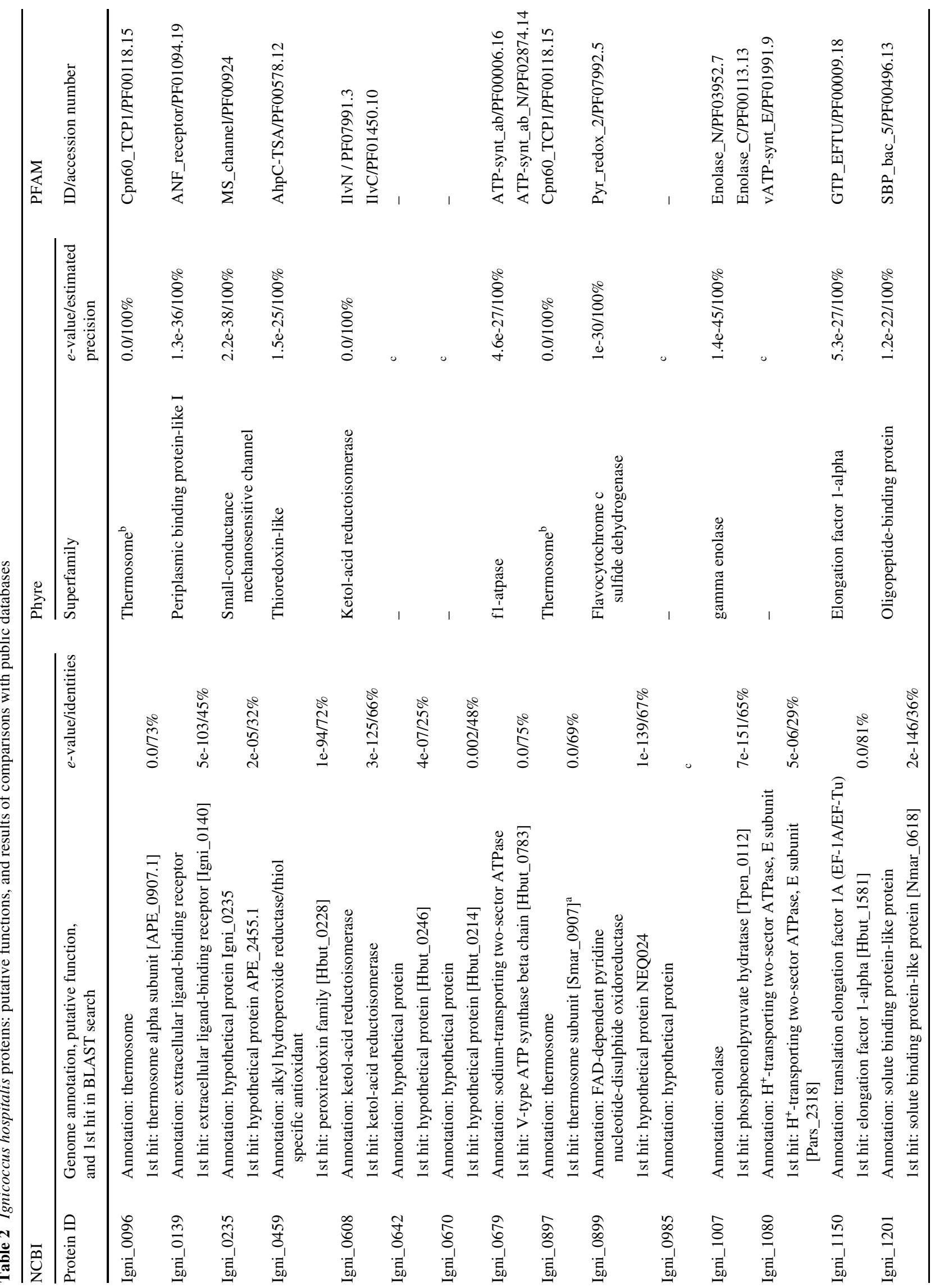




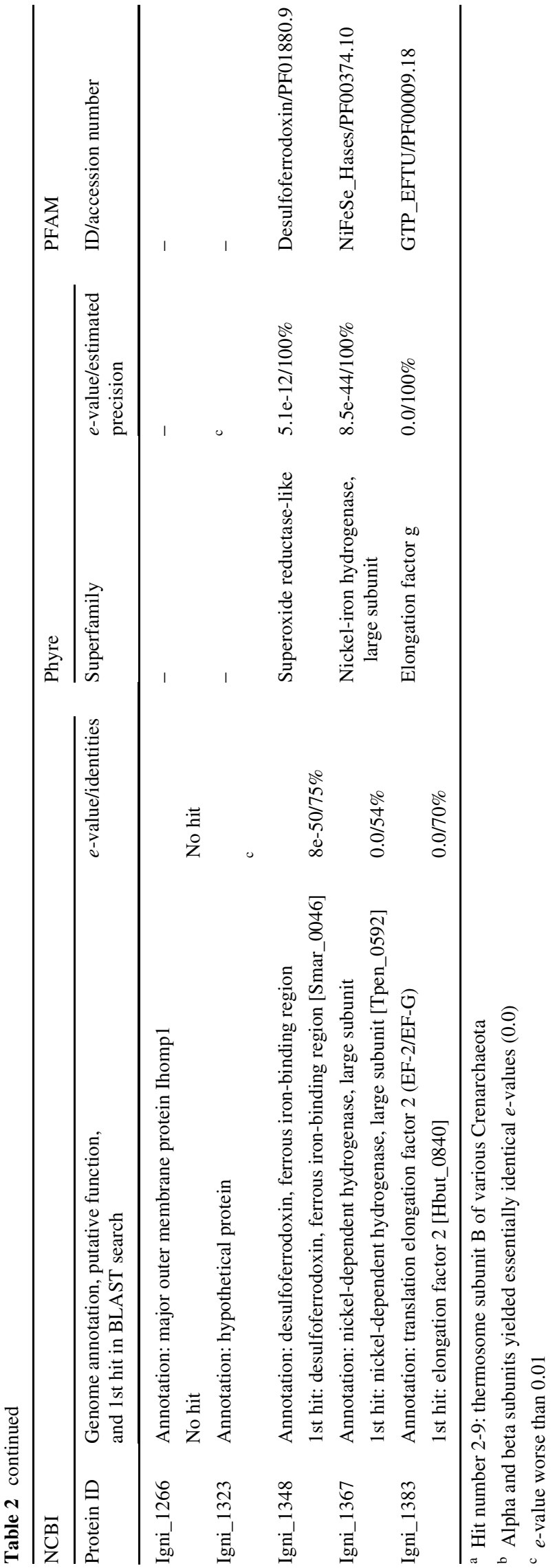

genome (igni_0316). Prxs are generally highly abundant proteins, to compensate for their low catalytic activities; and homologous proteins are found in many Archaea and Bacteria (e.g., using Blast; Table 3), where they are key antioxidants in the cytoplasm, ensuring survival of the cells under oxidative stress (Boucher et al. 2006). Based on the number of cysteine residues involved in catalysis, two groups are known, the 1-cys Prx and the 2-cys Prx; 1-cys Prxs only have a peroxidatic Cys in the N-terminus (e.g., ${ }^{49} \mathrm{Cys}$, like in the Sulfolobus solfataricus Prx; Limauro et al. 2006), while 2-cys Prxs have two, a peroxidatic Cys and a resolving Cys (e.g., ${ }^{50} \mathrm{Cys}$ and ${ }^{213} \mathrm{Cys}$ in Aeropyrum pernix; Nakamura et al. 2006). We suggest that the I. hospitalis Prx, although annotated as a member of the 1-cys Prx subfamily, also might be a 2-cys Prx: a pairwise alignment of the I. hospitalis and the Aeropyrum pernix enzyme strongly suggests that in I. hospitalis, ${ }^{48} \mathrm{Cys}$ may serve as the peroxidatic cysteine and ${ }^{209} \mathrm{Cys}$ as the resolving Cys; this needs to be determined experimentally. Using the structure prediction program 'Phyre', the best hit turned out to be with the Prx of Aeropyrum pernix; its 3D structure was determined by X-ray crystallography recently (Nakamura et al. 2006).

In fraction $\mathrm{C} 4$ of the sucrose gradient (Fig. 1a), two major soluble, i.e., cytosolic proteins were identified using two independent methods. TEM of negatively stained samples showed that they exclusively contain bulletshaped complexes, reminiscent to the thermosome or type II chaperone (Burghardt et al. 2007), as described for other Archaea, like Pyrodictium, Sulfolobus, or Methanopyrus (Phipps et al. 1993; Schoehn et al. 2000; Minuth et al. 1999). When separated by SDS-PAGE, this sample exhibited a characteristic double band with relative masses of approximately 60 and $58 \mathrm{kDa}$, respectively. A search in the I. hospitalis genome revealed the presence of exactly two genes which may code for these typical proteins: gene igni_0096, annotated as ThsA ( $\mathrm{Mr} 60,565 \mathrm{Da})$, and gene igni_0897, annotated as ThsB (Mr 58,827 Da). Both could be identified by MALDI-TOF MS/MS following tryptic digestion of the sample. The proteins belong to the cpn60 chaperonin family, which includes archaeal thermosomes, the eukaryal TCP1 complex, and the bacterial GroEL, enzyme complexes avoiding or reducing aggregation and accelerating protein folding (Ellis 2006). They share a unique quarternary structure, a double toroid of two stacked rings with seven or eightfold symmetry, as observed by TEM and image processing (e.g., Schoehn et al. 2000). The archaeal thermosome is described to be composed of two almost identical subunits, A and B, in all species investigated. Thermosome protein sequences are highly conserved, as revealed by a Blast search: The first 50 hits of a searches with Igni_0096 or Igni_0897 are all chaperones, with 49-69\% identical amino acids, including 
Table 3 Proteins from other microorganisms, with significant similarity to the $I$. hospitalis proteins found in this study

\begin{tabular}{|c|c|c|c|c|c|c|c|c|}
\hline Protein id & Putative function & $1^{\text {st }}$ hit & $2^{\text {nd }}$ hit & $3^{\text {rd }}$ hit & $4^{\text {th }}$ hit & $5^{\text {th }}$ hit & $6^{\text {th }}$ hit & $7^{7^{\text {th }} \text { hit }}$ \\
\hline Igni_0096 & thermosome subunit alpha & APE_0907.1 & Pocc, ThsA & Hbut_0918 & ThsA_SULSO & TF55- $\alpha \_S U L S O$ & Smar_1268 & ThsA_SULAC \\
\hline Igni_0139 & 'Binding protein' & Igni_0140 & Hbut_0616 & Tpen_1576 & Synechoc. & Csal_1418 & & \\
\hline Igni_0235 & Putative MscS channel & APE_2455.1 & Smar & Archfulg & Cmaq & & & \\
\hline Igni_0459 & $\begin{array}{l}\text { peroxiredoxin } \\
\end{array}$ & Hbut_0228 & Smar_0058 & Tpet_0121 & TM0807 & APE_2278 & Hore_1207 & Msed_1079 \\
\hline Igni_0608 & Ketol-acid reductoisomerase & $\begin{array}{l}\text { PAB0889 } \\
\end{array}$ & $\begin{array}{l}\text { PAE3298 } \\
\end{array}$ & Tneu_1541 & Pars_1722 & $\begin{array}{l}\text { Pisl_0552 } \\
\end{array}$ & $\begin{array}{l}\text { Pyrfu0936 } \\
\end{array}$ & Pcal_1755 \\
\hline Igni_0642 & hypothetical & Hbut_0246 & - & - & & & & \\
\hline Igni_0670 & Hypothetical / 'appendage' & Hbut_0214 & Cmaq_0418 & - & & & & \\
\hline Igni_0679 & $\mathrm{A}_{0} \mathrm{~A}_{1}$ ATP synthase $\mathrm{B}$ su & Hbut_0783 & ST1437 & VATB_APE & VATB_SULSO & VATB_SULAC & Msed_1918 & atpB_SULAC \\
\hline Igni_0897 & Thermosome, type II chap. & Smar_0907 & Hbut_0481 & APE_2072.1 & Pocc, ThsB & THSB_SULAC & THSB_SULSO & THSB_SULSH \\
\hline Igni_0899 & oxidoreductase & Neq024 & Pars_0242 & Pcal_1323 & Cmaq_1683 & PAE1131 & Msed_1039 & ST0971 \\
\hline Igni_0985 & hypothetical & - & & & & & & \\
\hline Igni_1007 & Enolase & Tpen_0112 & Smar_1274 & ENO_PYRFU & ENO_PYRHO & ENO_AQUAE & ENO_PYRKO & ENO_METKA \\
\hline Igni_1080 & $\mathrm{A}_{0} \mathrm{~A}_{1}$ ATP synthase $\mathrm{E}$ su & Pars_2318 & Msed_1916 & atpE_APE_040 & CTC00996 & CLB_2570 & Rumtor_01765 & Pcal_2088 \\
\hline Igni_1150 & EF1- $\alpha$ & Hbut_1581 & Smar_0810 & EF1A_APE & EF1A_DESMO & EF1A_SULSO & Msed_0041 & Saci_0685 \\
\hline Igni_1201 & 'Binding protein' & Nmar_0618 & CENSYa_1313 & Tneu_1418 & PAE3088 & Pcal_0975 & Pisl_0913 & Pars_1897 \\
\hline Igni_1266 & Major outer membrane protein 'Thomp1' & - & & & & & & \\
\hline Igni_1323 & $\begin{array}{l}\text { hypothetical } \\
\end{array}$ & - & & & & & & \\
\hline Igni_1348 & Desulfoferrodoxin & Smar_0046 & Hbut_1161 & Tpen_1830 & Tte2229 & Fnod_0468 & & \\
\hline Igni_1367 & $\mathrm{Ni} / \mathrm{Fe}$ dependent hydrogenase, large su & Tpen_0592 & Pcal_1578 & Tneu & $\begin{array}{ll}\text { Pisl_0197 } \\
\end{array}$ & Pars_1298 & Hbut_1368 & Acidambiv \\
\hline Igni_1383 & EF2 & Hbut_0840 & Smar_0866 & EF2_APE & EF2_ST & EF2_SULAC & Msed_0084 & EF2_DESMO \\
\hline
\end{tabular}

Abbreviations: chap., chaperone; su, subunit; EF, elongation factor

\begin{abstract}
NANOarchaeota: Neq: Nanoarchaeum equitans.
CRENarchaeota: Acidambiv: Acidianus ambivalens; APE: Aeropyrum pernix; Censy: Cenarchaeum symbiosum; Cmaq: Caldivirga maquilingensis; DESMO: Desulfurococcus mobilis; Hbut: Hyperthermus butylicus; Igni: Ignicoccus hospitalis; Msed: Metallosphaera sedula; Nmar: Nitrosopumilus maritimus; PAE: Pyrobaculum aerophilum; Pars: Pyrobaculum arsenaticum; Pcal: Pyrobaculum calidifontis; Pisl: Pyrobaculum islandicum; Pocc: Pyrodictium occultum; Saci: Sulfolobus acidocaldarius; Smar: Staphylothermus marinus; ST: Sulfolobus tokodaii; SULAC: Sulfolobus acidocaldarius; SULSH: Sulfolobus shibatae; SULSO: Sulfolobus solfataricus; Tneu: Thermoproteus neutrophilus; Tpen: Thermofilum pendens EURYarchaeota: Archfulg: Archaeoglobus fulgidus; METKA: Methanopyrus kandleri; PAB: Pyrococcus abyssi; PYRFU Pyrococcus furiosus; PYRHO Pyrococcus horikoshii; PYRKO
\end{abstract} Thermococcus kodakarensis;

BACTERIA: AQUAE: Aquifex aeolicus; CLB: Clostridium botulinum; Csal: Chromohalobacter salexigens; CTC: Clostridium tetani; Fnod: Fervidobacterium nodosum; Hore: Halothermothrix orenii; Rumtor Ruminococcus torques; Synechoc: Synechococcus sp.; TM: Thermotoga maritima; Tpet: Thermotoga petrophila; Tte: Thermoanaerobacter tengcongensis;

archaeal thermosome A and B subunits (Table 3) (Archibald et al. 1999). The crystal structure of the intact thermosome, containing both thermosome subunits, A and B, from T. acidophilum is known (Ditzel et al. 1998); the fold of the I. hospitalis ThsB, when predicted using 'Phyre', is in perfect agreement with the fold as described (data not shown).

In the centre of $\mathrm{CsCl}$ gradients of cell lysates obtained by thawing only, fractions predominantly containing ribosomes were identified: TEM analysis of negatively stained samples showed a mixture of asymmetric particles (Fig. 3a), about 25, 17, and $14 \mathrm{~nm}$ in diameter, equivalent to intact ribosomes, large subunits (50S), and small subunits (30S). This sample contained, according to SDSPAGE, more than 20 proteins in a size range of about 40 $10 \mathrm{kDa}$ (Fig. 3b; Londei et al. 1983).

\section{Membrane protein preparations}

Membrane preparations were isolated from lysed cells and enriched by three steps of ultracentrifugation as described in Sect. 'Materials and methods', resulting in a brownish pellet. Using 1D SDS-PAGE, a variety of proteins were found, in the relative mass range of about $85-25 \mathrm{kDa}$, and many weak bands with higher and lower apparent mass and varying intensity (Fig. 1b). Eight main bands, marked by white ellipsoids, were excised from the Coomassie-stained gel and further analyzed by N-terminal sequencing and/or mass spectrometry.

The protein in the uppermost band between 70 and $100 \mathrm{kDa}$ (Fig. 1b), when digested with trypsin and analyzed by MALDI-TOF MS/MS, was identified as the large subunit (Igni_1367; Mr 74,194 Da) of a putative Ni (or Ni/Fe) dependent hydrogenase. It is part of a multisubunit complex, one of the key membrane protein complexes in $I$. hospitalis for energy production and conversion, for gaining metabolic energy via sulfur respiration (Hedderich et al. 1999; Huber et al. 2000; Paper et al. 2007). A similar enzyme complex was isolated and biochemically analyzed in detail from anaerobically grown cells of Acidianus ambivalens (Laska et al. 2003), and also from cells of two Pyrodictium species, Pyrodictium brockii (Pihl and Maier 1991) and Pyrodictium abyssi (Dirmeier et al. 1998). Like all Ignicoccus species, these Archaea are able to thrive by $\mathrm{H}_{2} / \mathrm{S}^{0}$ chemolithoautotrophy (Hedderich et al. 1999). A Blast search with Igni_1367 revealed striking similarities (about 50\% identical amino acids) with homologous proteins from other, recently fully sequenced Crenarchaeota, all of which are able to use hydrogen as electron donor, i.e., as major energy source (Table 3) (Hedderich et al. 1999). In contrast, hydrogenase large subunits of microorganisms belonging to other domains had significantly less identical 

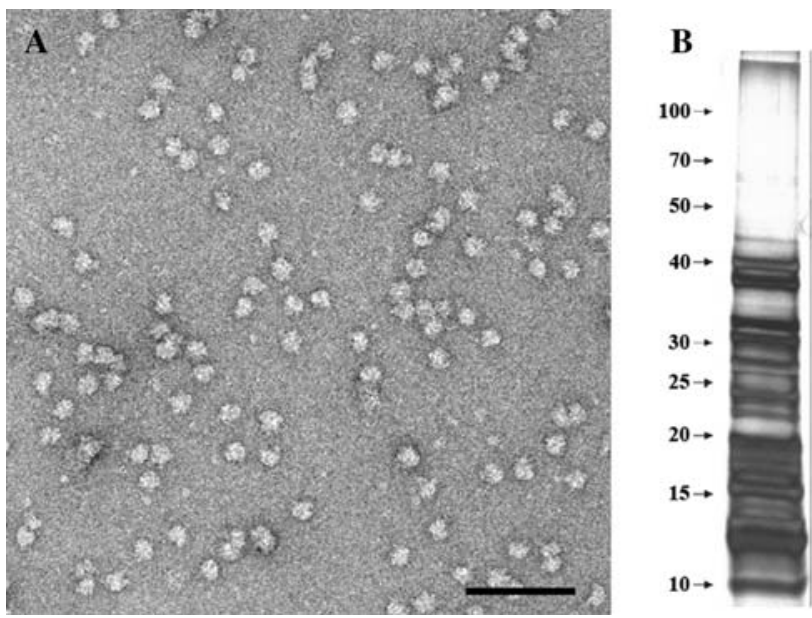

Fig. 3 Ribosomes of I. hospitalis, isolated from a fraction obtained by $\mathrm{CsCl}$-ultracentrifugation of cell lysate. a Transmission electron micrograph, negative staining by $2 \%$ uranyl acetate. Bar, $100 \mathrm{~nm}$. b SDSPAGE of the ribosomal proteins of the same sample. Numbers indicate relative mass in $\mathrm{kDa}$

amino acids (37\% or below). Obviously, physiological constraints, the use of hydrogen as electron donor and energy source, led to the evolution of (at least) this hydrogenase subunit as part of a membrane-bound complex in these phylogenetically related, thermophilic Crenarchaeota.

Although found in the membrane protein fraction, the protein Igni_1367 contains no TMD, according to the analysis with TMHMM 2.0 (or other programs). A closer look into the I. hospitalis genome reveals that the gene coding for this protein appears to be organized in one operon with three other genes, igni_1366, igni_1368, and igni_1369. Igni_1366 is predicted to contain a motif for TAT; predicted with TatFind; Rose et al. 2002), i.e., for transport of 'native', folded proteins, and a putative C-terminal transmembrane helix, possibly a membrane anchor. Gene igni_1368 is a putative subunit of the hydrogenase complex with five TMDs, and igni_1369 is annotated as a "4Fe-4S ferredoxin'. All these predictions, e.g., whether gene igni_1367 is co-transcribed and the resulting protein cotransported with Igni_1366, need to be verified experimentally.

The bands at apparent masses of approximately 69 and $64 \mathrm{kDa}$ (second and fourth band; Fig. 1b) exhibited blocked $\mathrm{N}$-termini. Mass spectrometric analyses of tryptic peptides helped to identify both proteins to be products of gene igni_0679, which is annotated to code for a 'V-type ATP synthase beta chain'. Why it appears in two different bands whose apparent mass deviates from the predicted mass of $52,268 \mathrm{Da}$, remains unclear; it might be a result from incomplete unfolding or aggregation upon denaturation. In other experiments, a band at an apparent mass of about $53 \mathrm{kDa}$ was identified to contain this protein (not shown).
Most likely, it is the $\mathrm{B}$ chain of the I. hospitalis $\mathrm{A}_{\mathrm{O}} \mathrm{A}_{1}$ ATP synthase (EC 3.6.3.15). This complex is another key enzyme for energy conversion, and a member of the rotary motors present in all life forms which use $\mathrm{Na}^{+}$or $\mathrm{H}^{+}$gradients for generating ATP (recent reviews: Lewalter and Müller 2006; Mulkidjanian et al. 2007). The subunit composition and function of this complex, including its dependence of $\mathrm{Na}^{+}$or $\mathrm{H}^{+}$gradients, is currently under investigation. An intact ATPase complex from another Crenarchaeon, Pyrodictium abyssi, was shown to be able to synthesize ATP even at $100^{\circ} \mathrm{C}$ (Dirmeier et al. 2000). The protein Igni_0679 is annotated to possess all known parts of a typical a/b type subunit, including an $\mathrm{N}$-terminal beta-barrel domain, a central region with a Walker $\mathrm{A}$ and a Walker $\mathrm{B}$ motif, and a typical C-terminal domain. The first 50 'similar' proteins found in the protein databases (NCBI; EMBLEBI) have 60-76\% identical amino acids, and the most similar proteins are found in species from the Crenarchaeota, which have-according to their 16S rRNA sequence (Burggraf et al. 1997) — a close phylogenetic relationship to I. hospitalis (Table 3).

The two bands at 50 and $45 \mathrm{kDa}$ (Fig. 1a, M; Fig. 1b) had identical N-termini ( $\mathrm{N}^{\prime}$-GIGYTAVIALAALV) and were identified as the main protein of the I. hospitalis outer membrane, encoded by gene igni_1266. The protein can directly be purified from patches of the Ignicoccus outer membrane in good yield (Burghardt et al. 2007). It was characterized and described recently, but with a different name and gene number: 'Imp1227', Ignicoccus outer Membrane Protein 1227; the number refers to an earlier version of gene numbering (Burghardt et al. 2007). We refer to this protein from now on as 'Ihomp1', I. hospitalis outer membrane protein one. Using Blast, no proteins can be found in any of the databases exhibiting significant similarities, today. Gene igni_1266 is annotated to code for a 'hypothetical protein' with 85 amino acids and a relative mass of $8,257 \mathrm{Da}$. The direct determination of the $\mathrm{N}$-terminus of the mature protein reveals that the protein is synthesized as a precursor including a leader peptide, which is cleaved off during transport to the outer membrane, resulting in a monomeric, mature protein with a mass of 6,230 Da only. The signal cleavage site is not predicted by any software, neither by FlaFind, nor TatFind or SignalP. The signal peptide of Igni_1266 is, according to the annotation, 18 amino acids in length. It will be challenging to determine in vitro which type of signal peptidase or, more general, aminopeptidase is responsible for the maturation of this protein, by cleavage between the two glycine residues (cf. Szabó et al. 2007). The observed two bands at about 50 and $40 \mathrm{kDa}$ (Fig. 1a, M; Fig. 1b) are explained by the presence of thermostable, oligomeric complexes resulting in anomalous migration behavior in SDS-PAGE, after solubilization at temperatures below $100^{\circ} \mathrm{C}$. Complete denaturation can 
only be achieved at temperatures exceeding $110^{\circ} \mathrm{C}$ (Burghardt et al. 2007), leading to a single band at about $10 \mathrm{kDa}$. In the course of this study, resequencing and analysis by mass spectrometry confirmed that this is indeed the product of gene igni_1266, with a mass of 6,230 Da. In addition, Nterminal sequencing of this band gave evidence for a second small, hydrophobic protein in low amounts $\left(\mathrm{N}^{\prime}\right.$ XXANMEANQ), as a minor component of the outer membrane. It is encoded by gene igni_1323, has 92 amino acids and a predicted mass of 9,949 Da. With the identified N-terminus, the signal peptide is 20 amino acid in length; the mature protein has 72 amino acids, a mass of 7,884 Da and two putative TMDs. Again, proteins with significant similarities are not found in the databases. It is worth mentioning that the neighbouring gene igni_1322 codes for another small, hydrophobic, 'hypothetical protein' with similar features, a signal peptide, two putative transmembrane helices, and a total mass below $10 \mathrm{kDa}$.

A peculiarity of the I. hospitalis outer membrane proteins 'Ihomp1' and Igni_1323 is that they have 20 amino acids in the $\mathrm{N}$-terminal or central part of the mature protein which have been determined or are predicted to form an $\alpha$ helical TMD (Burghardt et al. 2007). In contrast, proteins with $\alpha$-helical TMDs are rarely found in outer membranes of Gram-negative Bacteria. The most common protein fold for these proteins is a $\beta$-barrel, in various types (Schirmer 1998; Koebnik et al. 2000; Zeth et al. 2000; Nikaido 2003). A noteworthy exception of this rule for bacterial outer membrane proteins is the Wza protein, the translocon for capsular polysaccharides in the outer membrane of $E$. coli (Dong et al. 2006).

From the seventh protein band (Fig. 1b) at an apparent mass of $33 \mathrm{kDa}$, an $\mathrm{N}$-terminal sequence was obtained $\left(\mathrm{N}^{\prime}\right.$ VSPVIATLLL), which, in combination with tryptic digestion and MALDI-TOF MS/MS, helped to identify a protein encoded by gene igni_0670. It is annotated as a hypothetical protein with 310 amino acids; no proteins are found in the databases with significant similarities. FlaFind predicts a signal peptide of seven amino acids. SignalP also predicts the presence of a signal peptide but at the wrong cleavage site, between amino acid 23 and 24. Our experiences with SignalP are, not only in this case but for four proteins in total, not in line with the results of the direct determination of the N-termini. This can, in fact, be expected when using a bioinformatic program for archaeal proteins which is designed for predictions of eukaryotic and bacterial proteins. SignalP should, therefore, be used, very critically, as long as the program has not been trained accordingly. In the case of Igni_0670, the prediction by FlaFind is correct, as the N-terminus of the mature protein was determined to be at amino acid eight (provided that the translation start is annotated correctly, depending on which start codon is used; Torarinsson et al. 2005). Biochemical and electron microscopical investigations show that this protein is a component of extracellular appendages of I. hospitalis (D. Müller et al., in preparation); studies in our own laboratory to characterize this protein are almost finished and will be published soon.

From the band no. 8 (Fig. 1b) at an apparent mass of about $25 \mathrm{kDa}$, tryptic peptides were analyzed by MALDITOF MS/MS to identify products of two genes, igni_1080 and igni_0235. This came as no surprise, as the band at $25 \mathrm{kDa}$ always appeared fairly broad, suggesting that it contained two or more proteins.

The product of gene igni_1080 is annotated as a putative E subunit of a ' $\mathrm{H}^{+}$transporting two-sector ATPase', most likely the $I$. hospitalis $\mathrm{A}_{\mathrm{O}} \mathrm{A}_{1}$ ATP synthase. It has a predicted mass of $23,772 \mathrm{Da}$ and is hydrophilic, reflected in a high number of charged amino acids (42.3\%). The secondary structure of the putative E subunit is predicted to nearly exclusively contain $\alpha$-helices (Phyre). This is in accordance with its allocation as a peripheral, elongated subunit of the water-soluble $A_{1}$ part, the headpiece, in the present model of archaeal $\mathrm{A}_{\mathrm{O}} \mathrm{A}_{1}$ ATP synthases (Fig. 2 in Lewalter and Müller 2006). Using Blast, a similarity with putative $E$ subunits of other crenarchaeal $\mathrm{A}_{\mathrm{O}} \mathrm{A}_{1}$ ATPases was found, but with low significance only (Table 3; 29 and 27\% identical amino acids; $E$-values: 5e-06; 1e-04). When searching the genome for the corresponding gene, we noted that in $I$. hospitalis, genes coding for putative subunits of an $\mathrm{A}_{\mathrm{O}} \mathrm{A}_{1}$ ATP synthase are scattered in the genome, but not clustered in one operon, as in Methanocaldococcus jannaschii, in Methanosarcina mazei and other Archaea (Lewalter and Müller 2006).

A second protein with a predicted mass of $28,979 \mathrm{Da}$ and encoded by igni_0235, has 250 amino acids, $46.8 \%$ of which are apolar or aliphatic. TMHMM, SOSUI, and HMMTOP predict that its N-terminal part contains three TMDs, each about 23 amino acids in length, which indicates that this is a membrane protein. In the I. hospitalis genome, it is described as a 'putative uncharacterized protein'. A search in the protein databases at NCBI and EMBL-EBI revealed proteins similar in size, but with 22$28 \%$ identical amino acids only, in few Archaea (Table 3), annotated as 'putative MscS, mechanosensitive ion channel' (Hurst et al. 2008). In addition, there is a low similarity ( $<30 \%$ identical amino acids) with numerous proteins of Gram-negative bacteria, annotated as MscS, most of which have a significantly higher mass (above $80 \mathrm{kDa}$ ) than the archaeal counterparts $(\sim 25-30 \mathrm{kDa})$. A search for conserved protein domains (PFAM) supported the interpretation that this protein is related to $\mathrm{MscS}$ proteins ( $E$-value: 0.0077). A comparison of Igni_0235 to known 3D structures using Phyre also revealed the best hit to be the MscS protein of $E$. coli (Bass et al. 2002): it has only $15 \%$ amino acid identity to Igni_0235, but the structure model deter- 
mined for Igni_0235 has a reasonable $E$-value of 2.2e-38. This comparison suggests that both proteins have similar folds and structures, and let us propose as a working hypothesis that the I. hospitalis protein may exhibit a similar function as the MscS of E. coli which needs to be tested experimentally.

Two archaeal mechanosensitive channels were functionally characterized so far, from the Euryarchaeon Methanocaldococcus jannaschii; they have been cloned and shown upon reconstitution in liposomes to exhibit activities similar to bacterial Ms channels. They are, however, homologous to MscL of E. coli, a different class of Msc proteins (Kloda and Martinac 2001).

It is interesting to note that next to gene igni_0235, a gene is annotated coding for a putative $\mathrm{K}^{+}$uptake protein, with four TMDs (igni_0236: TrkA, with a TrkA-N and -C domain). A similar gene cluster is also found in the genome of Hyperthermus butylicus, with Hbut_0912 as a predicted $\mathrm{K}^{+}$transport protein, and Hbut_0913 as a hypothetical protein, possibly an MscS protein. It will be interesting to investigate whether these two membrane proteins, the $\mathrm{MscS}$ and the $\mathrm{K}^{+}$uptake protein, form a functional unit in the membrane of Crenarchaeota.

Membrane associated proteins separated by solubilization and gel filtration

Detailed analysis of the membrane fraction (Fig. 1, lane 7 and 8: M) was achieved by solubilization using $0.5 \%$ DDM at $25^{\circ} \mathrm{C}$, followed by gel filtration in the presence of low concentrations $(0.05 \%)$ of this detergent. Some fractions of the eluate, as screened by SDS-PAGE, are shown in Fig. 2. Thirteen of the protein bands were further analyzed by tryptic cleavage and MALDI-TOF MS/MS. The two bands at 45 and $40 \mathrm{kDa}$ (Fig. 2, fraction 1) were not analyzed further; according to results of our previous study (Burghardt et al. 2007) both are different forms of 'Ihomp1'. Five proteins already observed in previous experiments were identified again (Igni_1367; Igni_0899; Igni_0679; Igni_0670; Igni_0459; Fig. 2, ellipsoids with broken lines; Table 1). This indicates that the membrane fraction ' $M$ ' not only contained the outer membrane of I. hospitalis, as indicated in our previous paper (Burghardt et al. 2007), but also a significant amount of the cytoplasmic membrane. In addition, eight proteins were identified (Fig. 2, ellipsoids with solid lines; Table 1). For seven of these eight proteins, the identification was unambiguous: proteins with significant similarities were identified in the databases. Two of the newly identified proteins are annotated as 'ligand binding proteins', which are part of an ABC transporter or importer of unknown function (Hollenstein et al. 2007), and are, therefore, assumed to be associated with the cytoplasmic membrane (Igni_1201; Igni_0139). For the other six proteins, functions were annotated which point to a possible location in the cytoplasm. This shows that the experimental approach resulted in the separation of several fractions: first, the main outer membrane protein 'Ihomp1' (fractions of the gel filtration eluting before number 1 shown in Fig. 2; not shown); second, proteins integrated in or associated with the cytoplasmic membrane (Fig. 2, fractions 1,2), and third, contaminating proteins originating from the cytoplasm (fractions 3-5). The experiment did not result in the identification of yet unknown, integral membrane proteins, but in the detergent-induced dissociation of cytosolic and membrane/membrane-associated proteins which were, for biological reasons, more or less tightly associated with the membrane(s).

The enolase (Igni_1007; phosphoenolpyruvate hydratase, or 2-phospho-D-glycerate hydrolase, catalysing the reversible dehydration of 2-phospho-D-glycerate to phosphoenolpyruvate as part of the glycolytic and gluconeogenesis pathways) is involved in the central carbon metabolism (Jahn et al. 2007). A 3D structure prediction using Phyre yields perfect agreement with the crystal structure described. The protein encoded by igni_0642 is annotated as 'hypothetical protein', and no homologous proteins were found in the databases, aside from a hit with moderate similarity ( $E$-value: $4 \mathrm{e}-07)$ to another hypothetical protein of Hyperthermus butylicus. The genes igni_1383 and igni_1150 code for two translation factors, EF2 and EF1- $\alpha$, which are associated with the ribosome (Stark et al. 1997). Gene igni_1201 codes for a putative '(oligopeptide) binding protein', with a mass of $87,730 \mathrm{Da}$ (apparent mass: $53 \mathrm{kDa}$ ), which was identified by its $\mathrm{N}$-terminus ( $\mathrm{N}^{\prime}$-GPGAKADLEL). Whether the anomalous migration is a result from partial folding or proteolysis is unknown. Proteins of this type are utilized by ABC transporters as periplasmic modules for high-affinity binding of 'solutes' (in fact a wide variety of substrates), before uptake of the solute is mediated (Davidson and Chen 2004). Igni_0139 is annotated as an 'extracellular ligandbinding protein' with a mass of 47,413 Da (apparent mass: $55 \mathrm{kDa}$ ). Effectively, proteins of this type are, as Igni_1201, periplasmic components of ABC transporters. According to the annotation, Igni_0608 is a ketol-acid reductoisomerase, EC 1.1.1.86, also named acetohydroxy acid isomeroreductase. It catalyses the conversion of acetohydroxy acids into dihydroxy valerates (pfam07991), and is a key enzyme in the biosynthesis of two branched-chain amino acids, isoleucine, and valine. The 14,093 Da protein Igni_1348 is annotated as a desulfoferrodoxin, a member of the superoxide reductases, enzymes, which remove superoxide by reducing it to hydrogen peroxide (Rodrigues et al. 2007). They are involved in biological mechanisms designed for protection from oxidative stress (Lombard et al. 2000). 
For each of the 20 proteins, Blast searches were done against the non-redundant protein database at NCBI (Tables 2,3). The $E$-values for the respective 1st hits (Table 2) varied considerably, from 0.0 to $2 \mathrm{e}-05$ or even 0.002. Nevertheless, for most proteins (except for Igni_0642), similar or homologous proteins are found in genomes of microorganisms which are, like I. hospitalis, members of the Crenarchaeota (according to the sequence of their 16S rRNA). Many hits were found to Hyperthermus butylicus (6 among 1st hits; 10 among 1st to 3rd hits) and Staphylothermus marinus (2 among 1st hits; 7 among 1st to 3rd hits), and also to (sequenced) members of the Thermoproteales and the Sulfolobales. A close phylogenetic relationship between these members of the Archaea is, therefore, not only found by comparing $16 \mathrm{~S}$ rRNA gene sequences or ribosomal proteins, but also by comparing proteins important in the physiology of these microorganisms, as shown here. These findings confirm that Crenarchaeota have evolved as a unique and independent phylogenetic line.

\section{Conclusion}

This study aimed to identify the quantitatively major proteins present in freshly grown cells of $I$. hospitalis. For many of the proteins, a putative function can be assigned; together with the knowledge of the subcellular fraction from which each protein is derived, a possible localization in the cell can be deduced (Fig. 4). Most of the proteins are similar to proteins also encoded in the genomes of closely related Archaea, in particular Crenarchaeota. Apart from ribosomes, present in several thousand copies, the abundant and most likely essential proteins found in the cytoplasm are designed to cope with oxidative stress (Prx; oxidoreductases; desulfoferrodoxin) and heat stress (thermosome). Two proteins are involved in the translation process, EF1 $\alpha$ and EF2. The detection of these proteins in I. hospitalis is in line with a recent study on the proteome of the Euryarchaeon T. acidophilum; its cytoplasm was shown to contain, among other complexes, huge amounts of ribosomes, thermosomes, Prx, and EF1- $\alpha$ (Sun et al. 2007).

Fig. 4 Ultrathin section of (half of an) I. hospitalis cell (adapted from Paper et al. 2007), indicating the (putative) distribution of the proteins identified in this study

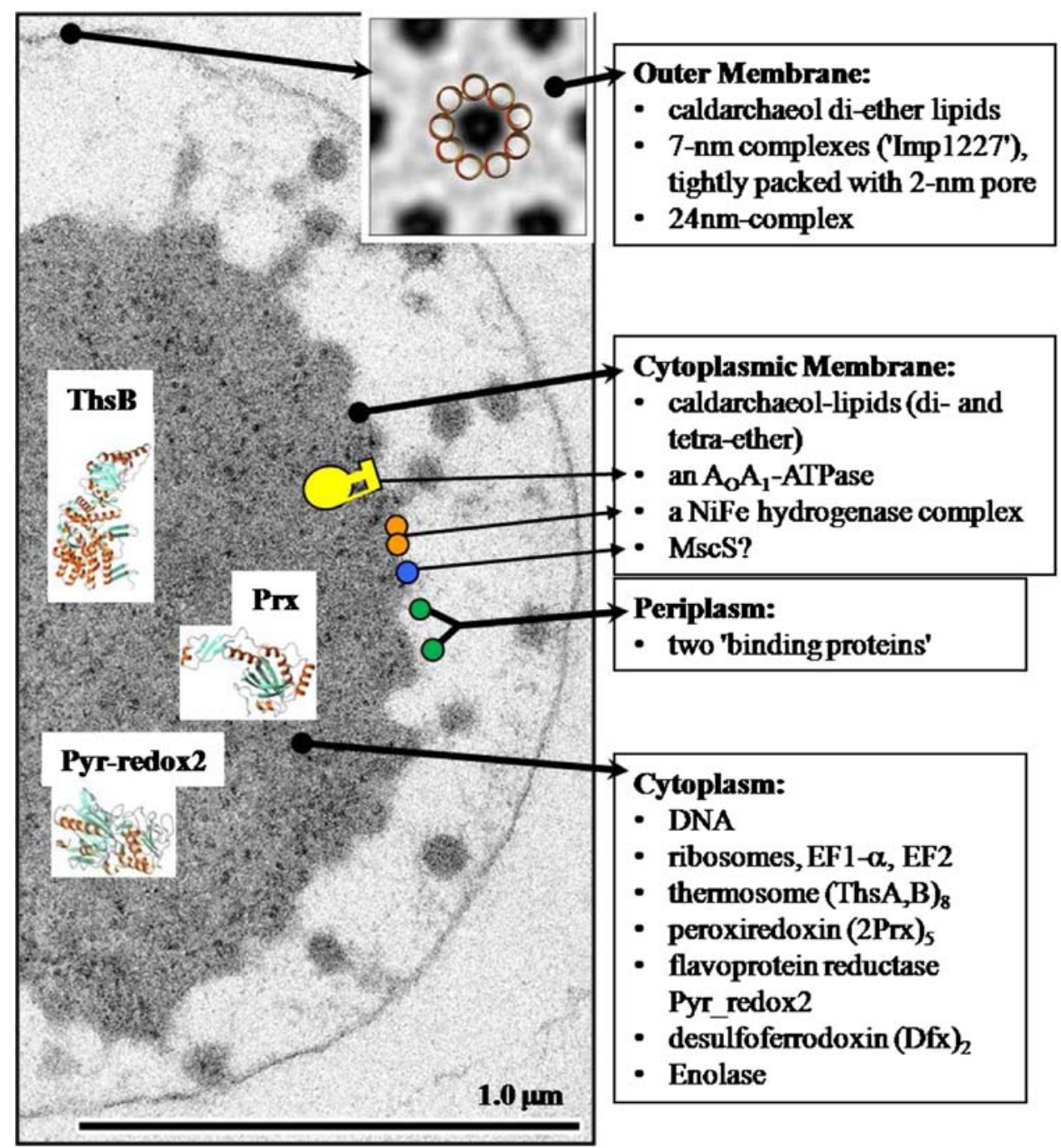


The dominant membrane protein in I. hospitalis 'Ihomp1' is the main protein of the unique outer membrane, which shields the cell from the hostile environment and builds up pores (whose function is under investigation); so far, it is exclusively found in this Archaeon and in no other organism. Other main membrane proteins are subunits of complexes involved in important cellular functions for gaining and transforming energy ( $\mathrm{NiFe}$ hydrogenase; ATP synthase); transport of yet unknown solutes (binding proteins) via putative $A B C$ transporters. Proteins involved in the sulfur reduction, although an important pathway in the lifestyle of I. hospitalis, were not yet identified. They had been found in other hyperthermophiles which use molecular hydrogen as energy source, in two related species of the Sulfolobales, as membrane protein complex in Acidianus ambivalens (Laska et al. 2003), and as transcript in Sulfolobus metallicus (Bathe and Norris 2007), and in membrane extracts of the hyperthermophilic bacterium Aquifex aeolicus (Guiral et al. 2005). This shows the limitation of our approach and makes technical improvements necessary in future studies (Klein et al. 2007).

One protein is found in I. hospitalis, Igni_0899, an oxidoreductase, which has its by far closest relative (with $67 \%$ identical amino acids) in N. equitans, the potential symbiont/parasite. The related oxidoreductases of two species of Pyrobaculum, a hyperthermophilic crenarchaeal genus which is more closely related to the genus Ignicoccus than $N$. equitans, show significantly less similarity to the Ignicoccus protein (50\% identical amino acids only). This suggests that the corresponding gene igni_0899/neq024 might have been transferred between the two, I. hospitalis and $N$. equitans. This is, in fact, not a singularity: a closer comparison of the genomes of $I$. hospitalis and $N$. equitans reveals nine further genes in I. hospitalis which, in a comparison with the NCBI database, have the first hit with a gene in the $N$. equitans genome, i.e., for which the most similar equivalent is found in the genome of $N$. equitans (T. Burghardt and R. Merkl, unpublished). This can be taken as a support for the hypothesis that there is not only a transport of lipids, amino acids, nucleotides, and cofactors, most likely unidirectional from $I$. hospitalis to $N$. equitans, but that also a gene transfer might have occurred between the two Archaea, possibly even in both directions.

In almost all cases, the functions of the proteins have been putatively assigned, but have not yet been tested directly in vivo or in vitro. No system is yet established for generating knock-outs in I. hospitalis, which could help to shed light onto possible functions. Our current investigations aim, therefore, to analyze some of the protein complexes identified, in both microorganisms: the ATP synthase, the extracellular appendages, membrane transport systems, and binding proteins which might be involved in the transport processes between both cells. In addition, the cellular distribution of these proteins is studied in both Archaea using immunolocalization on sections.

Acknowledgments The authors wish to thank K.O. Stetter and M. Thomm for continuous support and stimulating discussions, T. Hader and K. Eichinger for mass cultivation of cells, JGI for preliminary access to the genome data, and the anonymous reviewers for their valuable comments. The Ignicoccus sequence data were produced by the US Department of Energy Joint Genome Institute http://www. jgi.doe.gov/. This work was supported by a grant of the Deutsche Forschungsgemeinschaft to R. Rachel and H. Huber (Ra 751/5-1 and SPP1112).

\section{References}

Archibald JM, Logsdon JM Jr, Doolittle WF (1999) Recurrent paralogy in the evolution of archaeal chaperonins. Curr Biol 9:10531056

Bass RB, Strop P, Barclay M, Rees DC (2002) Crystal structure of Escherichia coli $\mathrm{MscS}$, a voltage-modulated and mechanosensitive channel. Science 298:1582-1587

Bathe S, Norris PR (2007) Ferrous iron- and sulfur-induced genes in Sulfolobus metallicus. Appl Environm Microbiol 73:2491-2497

Blum H, Beier H, Gross HJ (1987) Improved silver staining of plant proteins, RNA and DNA in polyacrylamide gels. Electrophoresis 8:93-99

Boucher IW, McMillan PJ, Gabrielsen M, Akeman SE, Brannigan JA, Schnick C, Brzozowski AM, Wilkinson AJ, Müller S (2006) Structural and biochemical characterization of a mitochondrial peroxiredoxin from Plasmodium falciparum. Mol Microbiol 61:948-959

Burggraf S, Huber H, Stetter KO (1997) Reclassification of the crenarchaeal orders and families in accordance with $16 \mathrm{~S}$ rRNA sequence data. Int J Syst Bacteriol 47:657-660

Burghardt T, Näther DJ, Junglas B, Huber H, Rachel R (2007) The dominating outer membrane protein of the hyperthermophilic archaeum Ignicoccus hospitalis: a novel pore-forming complex. Mol Microbiol 63:166-176

Davidson AL, Chen J (2004) ATP-binding cassette transporters in bacteria. Annu Rev Biochem 73:241-268

Dirmeier R, Keller M, Frey G, Huber H, Stetter KO (1998) Purification and properties of an extremely thermostable membrane-bound sulfur-reducing complex from hyperthermophilic Pyrodictium abyssi. Eur J Biochem 252:486-491

Dirmeier R, Hauska G, Stetter KO (2000) ATP synthesis at $100^{\circ} \mathrm{C}$ by an ATPase purified from the hyperthermophilic archaeon Pyrodictium abyssi. FEBS Lett 467:101-104

Ditzel L, Löwe J, Stock D, Stetter KO, Huber H, Huber R, Steinbacher $S$ (1998) Crystal structure of the thermosome, the archaeal chaperonin and homolog of CCT. Cell 93:125-138

Dong C, Beis K, Nesper J, Brunkan-LaMontagne AL, Clarke BR, Whitfield C, Naismith JH (2006) Wza the translocon for $E$. coli capsular polysaccharides defines a new class of membrane protein. Nature 444:226-229

Ellis RJ (2006) Inside the cage. Nature 442:360-362

Gasteiger E, Hoogland C, Gattiker A, Duvaud S, Wilkins MR, Appel RD, Bairoch A (2005) Protein identification and analysis tools on the ExPASy server. In: Walker JM (ed) The proteomics protocols handbook. Humana Press, Totowa, pp 571-607

Guiral M, Tron P, Aubert C, Gloter A, Iobbi-Nivol C, Giudic-Orticoni M-T (2005) A membrane-bound multienzyme, hydrogen-oxidizing, and sulfur-reducing complex from the hyperthermophilic Bacterium Aquifex aeolicus. J Biol Chem 280:42005-42015 
Hedderich R, Klimmek O, Kröger A, Dirmeier R, Keller M, Stetter KO (1999) Anaerobic respiration with elemental sulfur and with disulfides. FEMS Microbiol Rev 22:353-381

Hollenstein K, Frei DC, Locher KP (2007) Structure of an ABC transporter in complex with its binding protein. Nature 446:213-216

Huber H, Burggraf S, Mayer T, Wyschkony I, Rachel R, Stetter KO (2000) Ignicoccus gen. nov., a novel genus of hyperthermophilic, chemolithoautotrophic Archaea, represented by two new species, Ignicoccus islandicus sp. nov. and Ignicoccus pacificus sp. nov. Int J Syst Evol Microbiol 50:2093-2100

Hu , Hohn MJ, Rachel R, Fuchs T, Wimmer VC, Stetter KO (2002) A new phylum of Archaea represented by a nanosized hyperthermophilic symbiont. Nature 417:63-67

Huber H, Gallenberger M, Jahn U, Eylert E, Berg IA, Kockelkorn D, Eisenreich W, Fuchs G (2008) A dicarboxylate/4-hydroxybutyrate autotrophic carbon assimilation cycle in the hyperthermophilic Archaeum Ignicoccus hospitalis. Proc Natl Acad Sci USA 105:7851-7856

Hurst AC, Petrov E, Kloda A, Nguyen T, Hool L, Martinac B (2008) $\mathrm{MscS}$, the bacterial mechanosensitive channel of small conductance. Int J Biochem Cell Biol 40:581-585

Jahn U, Summons R, Sturt H, Grosjean E, Huber H (2004) Composition of the lipids of Nanoarchaeum equitans and their origin from its host Ignicoccus sp. strain KIN4/I. Arch Microbiol 182:404-413

Jahn U, Huber H, Eisenreich W, Hügler M, Fuchs G (2007) Insights into the autotrophic $\mathrm{CO}_{2}$ fixation pathway of the archaeon Ignicoccus hospitalis: comprehensive analysis of the central carbon metabolism. J Bacteriol 189:4108-4119

Jahn U, Gallenberger M, Paper W, Junglas B, Eisenreich W, Stetter KO, Rachel R, Huber H (2008) Nanoarchaeum equitans and Ignicoccus hospitalis: new insights into a unique, intimate association of two Archaea. J Bacteriol 190:1743-1750

Junglas B, Briegel A, Burghardt T, Walther P, Wirth R, Huber H, Rachel R (2008) Ignicoccus hospitalis and Nanoarchaeum equitans: ultrastructure, cell-cell interaction, and 3D reconstruction from serial sections of freeze-substituted cells and by electron cryotomography. Arch Microbiol (in press). doi:10.1007/s00203008-0402-6

Kaell L, Krogh A, Sonnhammer ELL (2007) Advantages of combined transmembrane topology and signal peptide prediction- the Phobius server. Nucleic Acids Res 35:W429-W432

Klein C, Garcia-Rizo C, Bisle B, Scheffer B, Zischka H, Pfeiffer F, Siedler F, Oesterhelt D (2005) The membrane proteome of Halobacterium salinarum. Proteomics 5:180-197

Klein C, Aivaliotis M, Olsen JV, Falb M, Besir H, Scheffer B, Bisle B, Tebbe A, Konstantinidis K, Siedler F, Pfeiffer F, Mann M, Oesterhelt D (2007) The low molecular weight proteome of Halobacterium salinarum. J Proteome Res 6:1510-1518

Kloda A, Martinac B (2001) Molecular identification of a mechanosensitive channel in Archaea. Biophys J 80:229-240

Koebnik R, Locher KP, van Gelder P (2000) Structure and function of bacterial outer membrane proteins: barrels in a nutshell. Mol Microbiol 37:239-253

König H, Rachel R, Claus H (2007) Proteinaceous surface layers of Archaea: ultrastructure and biochemistry. In: Cavicchioli R (ed) Archaea-molecular and cellular biology. ASM Press, Washington, pp 315-340

Krogh A, Larsson B, von Heijne G, Sonnhammer ELL (2001) Predicting transmembrane protein topology with a hidden Markov model: application to complete genomes. J Mol Biol 305:567-580

Laska S, Lottspeich F, Kletzin A (2003) Membrane-bound hydrogenase and sulfur reductase of the hyperthermophilic and acidophilic archaeon Acidianus ambivalens. Microbiology 149:2357-2371

Lewalter K, Müller V (2006) Bioenergetics of Archaea: ancient energy conserving mechanisms developed in the early history of life. Biochim Biophys Acta 1757:437-445
Limauro D, Pedone E, Pirone L, Bartolucci S (2006) Identification and characterization of 1-Cys peroxiredoxin from Sulfolobus solfataricus and its involvement in the response to oxidative stress. FEBS J 273:721-731

Lombard M, Fontecave M, Touati D, Nivière V (2000) Reaction of the desulfoferrodoxin from Desulfoarculus baarsii with superoxide anion. J Biol Chem 275:115-121

Londei P, Teichner A, Cammarano P (1983) Particle weights and protein composition of the ribosomal subunits of the extremely thermophilic archaebacterium Caldariella acidophila. Biochem $\mathrm{J}$ 209:461-470

Minuth T, Henn M, Rutkat K, Andrä S, Frey G, Rachel R, Stetter KO, Jaenicke R (1999) The rekombinant thermosome from the hyperthermophilic archaeon Methanopyrus kandleri: in vitro analysis of its chaperone activity. Biol Chem 380:55-62

Mulkidjanian AY, Makarova KS, Galperin MY, Koonin EV (2007) Inventing the dynamo machine: the evolution of the F-type and $\mathrm{V}$ type ATPases. Nat Rev Microbiol 5:892-899

Nakamura T, Yamamoto T, Inoue T, Matsumura H, Kobayashi A, Hagihara Y, Uegaki K, Ataka M, Kai Y, Ishikawa K (2006) Crystal structure of thioredoxin peroxidase from aerobic hyperthermophilic archaeon Aeropyrum pernix. Proteins 62:822-826

Näther DJ, Rachel R (2004) The outer membrane of the hyperthermophilic archaeon Ignicoccus: dynamics, ultrastructure and composition. Biochem Soc Trans 32:199-203

Nikaido H (2003) Molecular basis of bacterial outer membrane permeability revisited. Microbiol Mol Biol Rev 67:593-656

Paper W, Jahn U, Hohn MJ, Kronner J, Näther DJ, Burghardt T, Rachel R, Stetter KO, Huber H (2007) Ignicoccus hospitalis sp. nov., the host of 'Nanoarchaeum equitans'. Int J Syst Evol Microbiol 57:803-808

Phipps B, Typke D, Hegerl R, Volker S, Hoffmann A, Stetter KO, Baumeister W (1993) Structure of a molecular chaperone from a thermophilic archaebacterium. Nature 361:475-477

Pihl TD, Maier RJ (1991) Purification and characterization of the hydrogen uptake hydrogenase from the hyperthermophilic archaebacterium Pyrodictium brockii. J Bacteriol 173:18391844

Rachel R, Wyschkony I, Riehl S, Huber H (2002) The ultrastructure of Ignicoccus: evidence for a novel outer membrane and for intracellular vesicle budding in an archaeon. Archaea 1:9-18

Rodrigues JV, Saraiva LM, Abreu IA, Teixeira M, Cabelli DE (2007) Superoxide reduction by Archaeoglobus fulgidus desulfoferrodoxin: comparison with neelaredoxin. J Biol Inorg Chem 12:248-256

Rose RW, Brüser T, Kissinger JC, Pohlschröder M (2002) Adaptation of protein secretion to extremely high salt concentrations by extensive use of the twin arginine translocation pathway. Mol Microbiol 5:943-950

Schägger H, von Jagow G (1987) Tricine-sodium dodecyl sulfatepolyacrylamide gel electrophoresis for the separation of proteins in the range from 1 to $100 \mathrm{kDa}$. Anal Biochem 166:368-379

Schirmer T (1998) General and specific porins from bacterial outer membranes. J Struct Biol 121:101-109

Schoehn G, Hayes M, Cliff M, Clarke AR, Saibil HR (2000) Domain rotations between open, closed and bullet-shaped forms of the thermosome, an archaeal chaperonin. J Mol Biol 301:323-332

Soppa J, Baumann A, Brenneis M, Dambeck M, Hering O, Lange M (2008) Genomics and functional genomics with haloarchaea. Arch Microbiol (in press). doi:10.1007/s00203-008-0376-4

Stark H, Rodnina MV, Rinke-Appel J, Brimacombe R, Wintermeyer W, van Heel M (1997) Visualization of the elongation factor Tu on the Escherichia coli ribosome. Nature 389:403-406

Sun N, Beck F, Knispel RW, Siedler F, Scheffer B, Nickell S, Baumeister W, Nagy I (2007) Proteomics analysis of Thermoplasma acidophilum with a focus on protein complexes. Mol Cell Proteomics 6.3:492-502 
Szabó Z, Stahl AO, Albers S-V, Kissinger JC, Driessen AJM, Pohlschröder M (2007) Identification of diverse archaeal proteins with class III signal peptides cleaved by distinct archaeal prepilin peptidases. J Bacteriol 189:772-778

Torarinsson E, Klenk H-P, Garrett RA (2005) Divergent transcriptional and translational signals in Archaea. Environ Microbiol 7:47-54

Tusnády GE, Simon I (2001) The HMMTOP transmembrane topology prediction server. Bioinformatics 17:849-850

Waters E, Hohn MJ, Ahel I, Graham DE, Adams MD, Barnstead M et al (2003) The genome of Nanoarchaeum equitans: insights into early archaeal evolution and derived parasitism. Proc Natl Acad Sci USA 100:12984-12988

Wood ZA, Schroder E, Robin Harris J, Poole LB (2003) Structure, mechanism and regulation of peroxiredoxins. Trends Biochem Sci 28:32-40

Zeth K, Diederichs K, Welte W, Engelhardt H (2000) Crystal structure of Omp32, the anion-selective porin from Comamonas acidovorans, in complex with a periplasmic peptide at 2.1 A resolution. Structure 8:981-992 